Knut Benjamin Pißler

\title{
Wohnungseigentum in China
}

\author{
Darstellung und Rechtsgrundlagen
}

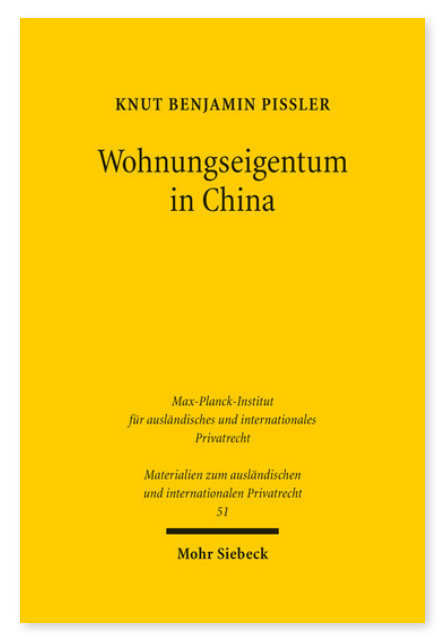

2012. XI, 210 Seiten. MatIPR 51

ISBN 978-3-16-152408-0

DOI 10.1628/978-3-16-152408-0

eBook PDF 79,00€

ISBN 978-3-16-152407-3

Leinen $79,00 €$
Mit der Verabschiedung des Sachenrechtsgesetzes in der Volksrepublik China in 2007 wurde auch das Recht des Wohnungseigentums auf eine gesetzliche Grundlage gestellt. Dort ist dieser Rechtsbereich jedoch nur sehr knapp geregelt. Eine detailliertere Ausgestaltung bleibt damit untergesetzlichen Normen und justiziellen Interpretationen des Obersten Volksgerichts überlassen. Knut Benjamin Pißler gibt deutschsprachigen Lesern einen Einblick in dieses Rechtsgebiet, das zugleich auch auf Fragen des Teileigentums an nicht zu Wohnzwecken dienenden Räumen eines Gebäudes Anwendung findet. Dabei geht er nach einigen Begriffsbestimmungen auf die Begründung von Wohnungseigentum, die Gemeinschaft der Eigentümer und die Verwaltung des Wohnungseigentums ein. Zugleich werden alle wesentlichen Rechtsakte, die im chinesischen Wohnungseigentumsrecht einschlägig sind, erstmals in einer deutschen Übersetzung vorgelegt.

Knut Benjamin Pißler ist Professor für chinesisches Recht an der Universität Göttingen, Lehrbeauftragter an den Universitäten Göttingen und Köln sowie wissenschaftlicher Referent am Max-Planck-Institut für ausländisches und internationales Privatrecht in Hamburg.

Jetzt bestellen:

https://mohrsiebeck.com/buch/wohnungseigentum-in-china-9783161524080?no_cache=1

order@mohrsiebeck.com

Telefon: +49 (0)7071-923-17

Telefax: $+49(0) 7071-51104$ 